\title{
11. Educating for professionalism in ICT: Is learning ethics professional development?
}

\author{
David Lindley, ${ }^{1}$ Brenda Aynsley, ${ }^{2}$ Michael Driver, \\ Robert Godfrey, ${ }^{3}$ Robert Hart, ${ }^{4}$ Glen Heinrich, ${ }^{5}$ \\ Bhuvan Unhelkar ${ }^{6}$ and Kim Wilkinson
}

\section{Introduction}

This paper considers professionalism as the product of a process; a status that can be achieved and justified by completing a series of activities. It does not attempt to explain what professionalism is, rather, it explains what the Australian Computer Society (ACS) deems professionals should know and be capable of doing.

In this paper, we aim to convey the following messages:

- Professionals require education beyond that offered in a typical university degree.

- The ACS Computer Professional Education (CPe) Program is constructed on the established Skills Framework for the Information Age (SFIA, 2008a) plus an additional skill set labelled Professionalism.

- To recognise information and communications technology (ICT) practitioners as ICT professionals, the ACS requires that they have a practical knowledge of ethics.

- Formal research is necessary to ascertain the effectiveness of the ACS approach to ethics education.

And, to justify these messages, we address the following questions:

- What is an ICT professional?

- Are there grades of ICT professionalism?

- What is professional development for ICT professionals?

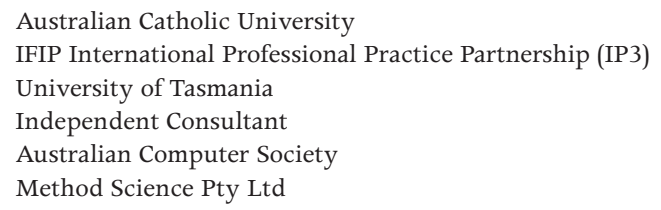


Professionalism in the Information and Communication Technology Industry

- Where, on the scale of academically oriented education versus competencybased training, does ICT professional development lie?

- How does the ACS achieve its learning objectives in teaching ethics?

- Are the techniques that the ACS uses good enough?

\section{What is an ICT professional?}

The ACS Professional Standards Board (2007) deems an ICT professional as someone eligible for its professional level of membership. That individual should possess the following knowledge, skills and capabilities:

- Factual and theoretical knowledge of ICT in broad contexts.

- Advanced, coherent body of knowledge in a discipline/field involving critical understanding of theories and principles.

- Advanced skills, demonstrating mastery and innovation required to solve complex and unpredictable problems in a discipline/field of ICT.

- Exercise management and supervision [skills] in contexts of work activities where there is unpredictable change.

- [Competent to] Take responsibility for complex technical and professional activities or projects.

- [Competent to] Review and develop performance of self and others.

In this context, the descriptors the ACS uses to define levels of membership can be stated as:

- Knowledge: facts, information and skills acquired through experience and education.

- Skills: the ability to perform a task.

- Capability: a standard necessary to perform a specific job.

Underpinning this choice of descriptors is the skills framework for the information age (SFIA), which is described as providing 'a common reference model for the identification of the skills needed to develop effective information systems (IS) making use of information technologies (IT)'.

SFIA is a two-dimensional table that represents skill sets on one dimension and levels of responsibility, or capability, on the other. A tabular view of SFIA subset is provided in Figure 1 below.

The ACS considers that graduates from most, but not all, Australian ICT degree programs can, after 18 months relevant industry experience, perform at SFIA Level of Responsibility 4 (Enable). With further experience, and studies within the ACS CPe program, its graduates are expected to have achieved SFIA Level of Responsibility 5 (Ensure, advise) and be eligible for professional level membership. 
11. Educating for professionalism in ICT: Is learning ethics professional development?

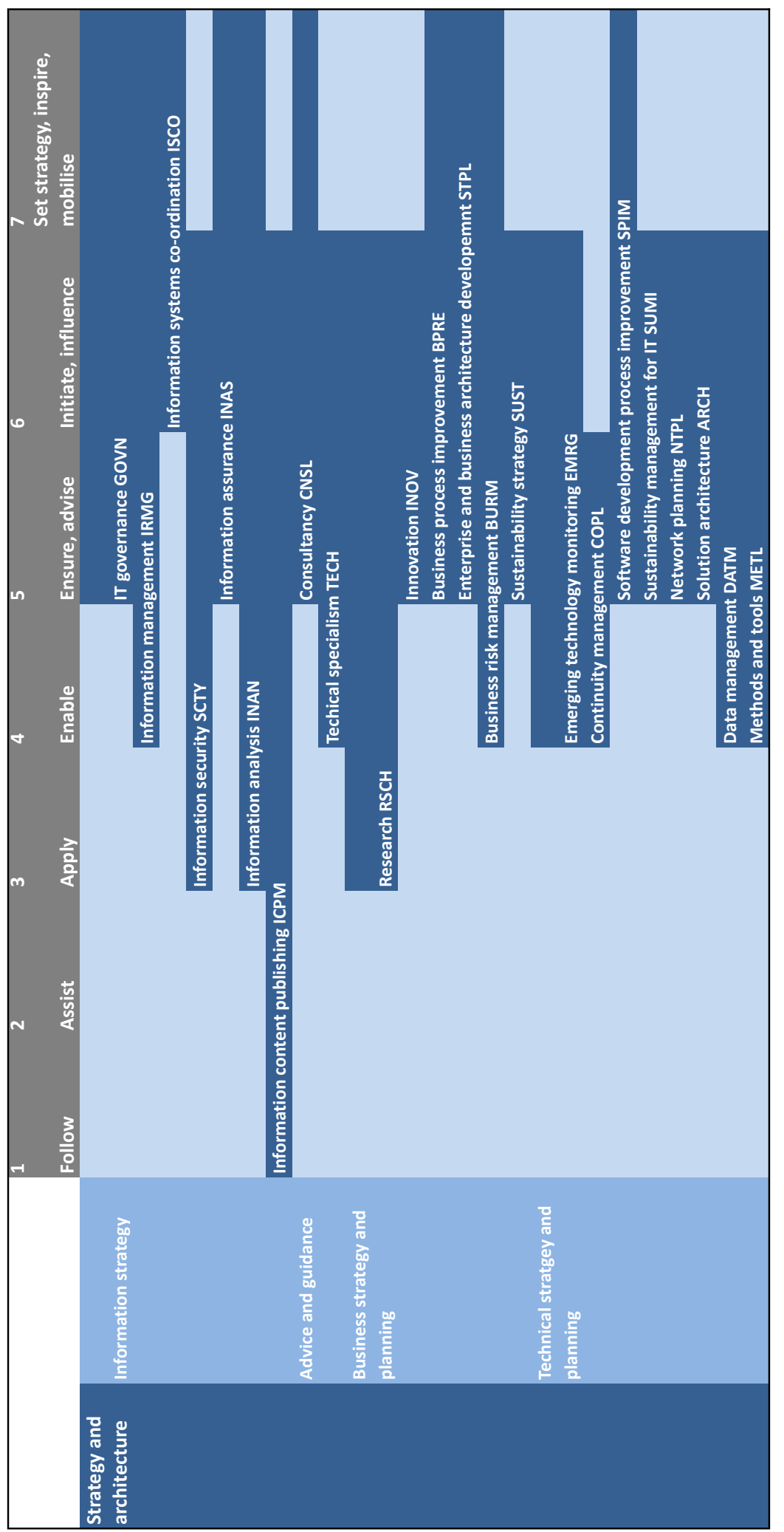

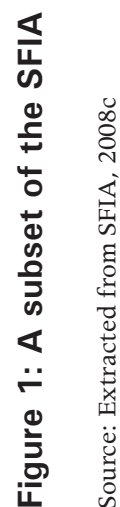


SFIA Levels of Responsibility 4 and 5 are defined Table la and $1 \mathrm{~b}$ below.

Table 1a: Definition of SFIA Level of Responsibility 4

\begin{tabular}{|l|l|}
\hline \multicolumn{2}{|c|}{ SFIA Level of Responsibility 4 (Enable) } \\
\hline Autonomy & $\begin{array}{l}\text { Works under general direction within a clear framework of accountability. } \\
\text { Substantial personal responsibility and autonomy. Plans own work, to meet } \\
\text { given objectives and processes. }\end{array}$ \\
\hline Influence & $\begin{array}{l}\text { Influences team, and specialist peers internally. Influences customers } \\
\text { at account level and suppliers. Some responsibility for work of others } \\
\text { and allocation of resources. Participates in external activities related to } \\
\text { specialisation. Decisions influence success of projects and team objectives. }\end{array}$ \\
\hline Business & $\begin{array}{l}\text { Broad range of complex technical or professional work activities in a variety } \\
\text { of contexts. }\end{array}$ \\
\hline $\begin{array}{l}\text { Selects appropriately from applicable standards, methods, tools and } \\
\text { applications and use. Demonstrates analytical and systematic approach } \\
\text { to problem solving. Communicates fluently orally and in writing and can } \\
\text { present complex technical information to both technical and non-technical } \\
\text { audiences. Is able to plan, schedule and monitor work activities in order } \\
\text { to meet time and quality targets and in accordance with health and safety } \\
\text { procedures. Is able to absorb rapidly new technical information and apply it } \\
\text { effectively. Good appreciation of wider field of information systems, its use } \\
\text { in relevant employment areas and how it relates to the business activities of } \\
\text { the employer or client. Maintains awareness of developing technologies and } \\
\text { their application and takes some responsibility for personal development. }\end{array}$ \\
\hline
\end{tabular}

Source: Extracted from SFIA, 2008c

Table 1b: Definition of SFIA Level of Responsibility 5

\begin{tabular}{|l|l|}
\hline \multicolumn{2}{|l|}{ SFIA Level of Responsibility 5 (Ensure, advise) } \\
\hline Autonomy & $\begin{array}{l}\text { Works under broad direction. Full accountability for own technical work } \\
\text { or project/supervisory responsibilities. Receives assignments in the form } \\
\text { of objectives. Establishes own milestones, team objectives and delegates } \\
\text { assignments. Work is often self-initiated. }\end{array}$ \\
\hline Influence & $\begin{array}{l}\text { Challenging range and variety of complex technical or professional work } \\
\text { activities. Work requires application of fundamental principles in a wide and } \\
\text { often unpredictable range of contexts. Understands relationship between } \\
\text { specialism and wider customer/ organisational requirements. }\end{array}$ \\
\hline Complexity & $\begin{array}{l}\text { Broad range of complex technical or professional work activities, in a } \\
\text { variety of contexts. }\end{array}$ \\
\hline Business & $\begin{array}{l}\text { Advises on the available standards, methods, tools and applications in own } \\
\text { area of specialisation and can make correct choices from alternatives. Can } \\
\text { analyse, diagnose, design, plan, execute and evaluate work to time, cost } \\
\text { and quality targets. Communicates effectively, formally and informally, } \\
\text { with colleagues, subordinates and customers. Demonstrates leadership. } \\
\text { Clear understanding of the relationship between own area of responsibility/ } \\
\text { specialisation to the employing organisation and takes customer } \\
\text { requirements into account when making proposals. Takes initiative to keep } \\
\text { skills up to date. Maintains awareness of developments in the industry. } \\
\text { Can analyse user requirements and advise users on scope and options } \\
\text { for operational improvement. Demonstrates creativity and innovation in } \\
\text { applying solutions for the benefit of the user. }\end{array}$ \\
\hline
\end{tabular}


While comprehensive in the range of skills it encompasses, SFIA has no skills category relevant to professionalism, or professional behaviour. To cover this area, the ACS has expanded on SFIA with an additional skill set that, for university and CPeP graduates, are defined in Table 2 below.

Table 2: Definitions of ACS professionalism skills

\begin{tabular}{|l|l|}
\hline \multirow{5}{*}{ SFIA Level of Responsibility } & $\begin{array}{l}\text { Develops a basic risk management plan for simple } \\
\text { projects including the impact on social, business and } \\
\text { ecological environments. }\end{array}$ \\
\cline { 2 - 2 } 4 (Professionalism skills of & $\begin{array}{l}\text { Identifies legal requirements and constraints imposed } \\
\text { on the work/project and contributes to compliance. }\end{array}$ \\
\cline { 2 - 3 } university graduates) & $\begin{array}{l}\text { Commits to a code of ethics, standards and practice } \\
\text { and can apply these in basic projects. }\end{array}$ \\
\cline { 2 - 2 } & $\begin{array}{l}\text { SFIA Level of Responsibility 5 (Professionalism skills of } \\
\text { CPeP graduates). }\end{array}$ \\
\cline { 2 - 2 } & $\begin{array}{l}\text { Develops a risk management plan for projects } \\
\text { including the impact on social, business and ecological } \\
\text { environments and ensures compliance. }\end{array}$ \\
\cline { 2 - 2 } & Ensures compliance with all legal/regulatory requirements. \\
\cline { 2 - 2 } & $\begin{array}{l}\text { Ensures compliance with appropriate professional codes } \\
\text { of ethics, standards and practice. }\end{array}$ \\
\hline
\end{tabular}

Source: Extracted from SFIA, 2008c

An ICT professional, therefore, is someone who has full accountability for their own technical work and responsibilities; whose decisions can impact on the success of projects; who develops business relationships with customers; who must apply fundamental principles in a wide and often unpredictable range of contexts; and, who can analyse, diagnose, design, plan, execute and evaluate work to time, cost and quality targets. In addition, they can communicate effectively, demonstrate leadership, and keep their skills up to date. They are creative, innovative, and aware of their impact on social, business and ecological environments. Their knowledge and actions are able to influence direction within the organisation, their peers and industry.

\section{Are there grades of ICT professionalism?}

An ICT professional, in the view of the ACS, is someone eligible for its professional level of membership. This level is not easily achieved and thus, in the view of the ACS, ICT professionals are a subset, perhaps a small subset, of the generality of ICT practitioners.

But the ease or difficulty of gaining ACS membership at the professional level is not the consideration here. It is whether membership at this level means 
something about the person who gains the professional level of membership and, therefore, also suggests something about other practitioners who are not members at the professional level.

The ACS professional level of membership aims to be a differentiator between ICT practitioners, who the ACS verifies as reliable and competent at SFIA level of responsibility 5, and others, who might be less than reliable at that level. Those with the ACS professional level of membership can use their membership as evidence for prospective employers and clients of their professional abilities. Those who are not ACS professional level members will require additional evidence, and additional corroboration, to justify similar claims.

Note that the ACS is not aiming to be elitist or exclusive with its professional level of membership. There are other levels of membership with less onerous prerequisites. The associate level, for instance, is mapped to the SFIA level of responsibility 3 (Apply). But it is the objective of the ACS for its members at these other levels to raise their knowledge, skills and capabilities to the level of the professional. The ACS aims to be both an inclusive organisation, and an organisation that encourages continuing professional development amongst its members.

Indicative of the ACS view of professionalism is that the majority of assessments in its CPe program do not have a grade for exceptional achievement. Instead, most items of assessment are graded 0,1 , or 2 - where 2 is measured as at or exceeds expectations. The ACS does not view professionalism in multiple grades. Rather, a person is either an ICT professional, or they are not. They either meet the criteria for membership at the professional level, or they do not. They can either take on professional responsibilities at SFIA level 5, or they cannot.

\section{What is professional development for ICT professionals?}

The ACS specifies its professional level of membership in terms of knowledge, skills and capability. Professions Australia defines a profession in similar terms; the possession of 'special knowledge and skills in a widely recognised body of learning derived from research, education and training at a high level' (Professions Australia, 1997).

Considering, again, the definitions of an ICT professional provided above, it seems reasonable now to define professional development as the acquisition of, and the continuing possession and use of, facts, information, and skills necessary to perform a task. 
It is important to distinguish between the 'acquisition of ... facts, information and skills', and the 'continuing possession of ... facts, information and skills'. The first is initial professional development (IPD), and the second is continuing professional development (CPD).

The UK Initial Professional Development Forum defines IPD as 'a period of development during which an individual acquires a level of capability necessary in order to operate as an autonomous professional'. It goes on to clarify the concept with the statement 'Professional bodies may recognise the successful completion of IPD by the award of chartered or similar status' (nd).

Engineers Australia states 'Continuing Professional Development (CPD) helps you maintain up-to-date technical skills and knowledge of processes, technology and legislation. It also enables you to attain and maintain your Chartered Status' (2009).

The ACS now follows a similar strategy. To achieve its professional level of membership, an applicant is required to have a minimum of four years relevant experience and, in addition, have completed a course of study encompassing the ACS core body of knowledge. This entitles an applicant to use the postnominal MACS (Member of the ACS).

But, to use the post-nominal MACS CP, indicating an ACS-recognised certified professional, a MACS must complete the ACS CPe program. Initial professional development, therefore, is a course of study, typically a university degree in some aspect of ICT, plus experience, plus postgraduate studies in professionalism (that is, the ACS CPe program).

Then, to maintain their CP status, a member must complete, annually, at least 30 hours of professional development; which is to say, continuing professional development. Unlike IPD, the ACS view of CPD is that it should be self-directed. Except for its quantity, and that it must be relevant to a practicing computer professional at SFIA level 5 or above, the ACS does not prescribe what the professional development must comprise.

\section{Where, on the scale of academically oriented education versus competency-based training, does ICT professional development lie?}

To achieve the ACS professional level of membership, an applicant requires a minimum of four years relevant experience plus the completion of a course 
of study encompassing the ACS core body of knowledge. The ACS, therefore, deems professionalism to be acquired only through a combination of education and experience.

It seems obvious that, if professionalism is defined in terms of knowledge, skills and capability, then a professional requires education beyond that offered in a typical diploma or degree. They require more than just knowledge, and more than just technical skills.

The professional requires contextual awareness; that is, how ICT, and the numerous ICT roles in industry, fit within and influence the world of business, society, and the environment. They also need a reasoned and objective assessment of themselves; their own knowledge, skills and capabilities. A person seeking a job on the basis of an innocent but incorrect assessment of their own ability is as unprofessional as a person who deliberately falsifies their résumé. And these two requirements lead to the skill set the ACS has added to those of SFIA, namely, the skills concerned with risk management.

So, where does ICT professional development lie on the academically oriented education versus competency-based training scale? It lies across the entire scale with, perhaps, IPD centred more towards the academically oriented end, and CPD more towards the competency-based end.

\section{What is achieved by teaching ethics?}

The ACS describes itself as a professional association. This suggests that the practice of ICT and computing-related activities is, or should be, a profession. An ICT practitioner in Australia, however, can claim to be an ICT professional even though, unlike practitioners in disciplines such as law and medicine, they do not need any form of registration or belong to a professional association.

Professions Australia describes a profession as 'a disciplined group of individuals who adhere to ethical standards ...' (1997). While it should not be assumed from this that ICT practitioners in Australia who do not belong to a professional association will necessarily behave unethically, it can be reasonably argued that the possibility of unethical behaviour is less likely if a person is educated and trained in the interpretation and application of ethical standards. Further, it can be argued that a person is less likely to behave unethically if they are subject to disciplinary processes by their peers; which is to say, their professional association.

ACS rules and regulations (nd) include a code of ethics, extracts of which are provided in Table 3 below. 
Table 3: Extract of ACS code of ethics

\begin{tabular}{|c|c|}
\hline $\begin{array}{l}4.1 \text { To uphold and advance the } \\
\text { honour, dignity and effectiveness } \\
\text { of the profession of information } \\
\text { technology and in keeping with high } \\
\text { standards of competence and ethical } \\
\text { conduct, a member must: }\end{array}$ & $\begin{array}{l}\text { (a) be honest, forthright and impartial, and } \\
\text { (b) loyally serve the community, and } \\
\text { (c) strive to increase the competence and prestige of } \\
\text { the profession, and } \\
\text { (d) use special knowledge and skill for the } \\
\text { advancement of human welfare. }\end{array}$ \\
\hline 4.3 Values and Ideals & $\begin{array}{l}\text { I must act with professional responsibility and integrity } \\
\text { in my dealings with the community and clients, } \\
\text { employers, employees and students. I acknowledge: } \\
\text { I must place the interests of the community above } \\
\text { those of personal or sectional interests. }\end{array}$ \\
\hline 4.3.2 Competence & $\begin{array}{l}\text { I must work competently and diligently for my } \\
\text { clients and employers. }\end{array}$ \\
\hline 4.3.3 Honesty & $\begin{array}{l}\text { I must be honest in my representation of skills, } \\
\text { knowledge, services and products. }\end{array}$ \\
\hline 4.3.4 Social Implications & $\begin{array}{l}\text { I must strive to enhance the quality of life of those } \\
\text { affected by my work. }\end{array}$ \\
\hline 4.3.5 Professional Development & $\begin{array}{l}\text { I must enhance my own professional development, } \\
\text { and that of my colleagues, employees and students. }\end{array}$ \\
\hline $\begin{array}{l}\text { 4.3.6 Information Technology } \\
\text { Profession }\end{array}$ & $\begin{array}{l}\text { I must enhance the integrity of the information } \\
\text { technology profession and the respect of its } \\
\text { members for each other. }\end{array}$ \\
\hline
\end{tabular}

Source: Taken from ACS rules and regulations (ACS, nd)

While the code of ethics is readily accessible to ACS members and people affected by their work, it comprises general and non-specific statements and often requires guidance in interpretation and application. This point is supported by the ACS standards of conduct, which state that 'A member is expected to take into account the spirit of the Code of Ethics in order to resolve ambiguous or contentious issues concerning ethical conduct'. In addition, the ACS has a code of professional practice and professional conduct, which is designed 'to provide members with authoritative guidance on acceptable standards of professional conduct and ... is not intended to include a multitude of detailed rules'. It goes on to say that the code should not be 'narrowly interpreted' (ACS, nd).

While the ACS offers formal education programs in professional ethics, a specialist intermediary is often required to apply the ACS code of ethics to professional practice in the real world.

Together with its code of ethics and supporting education activities, the ACS has implemented disciplinary procedures, see Table 4 below, which can be applied in the event that a member behaves in a manner inconsistent with the Code. 
Professionalism in the Information and Communication Technology Industry

Table 4: Nature of complaints and disciplinary action

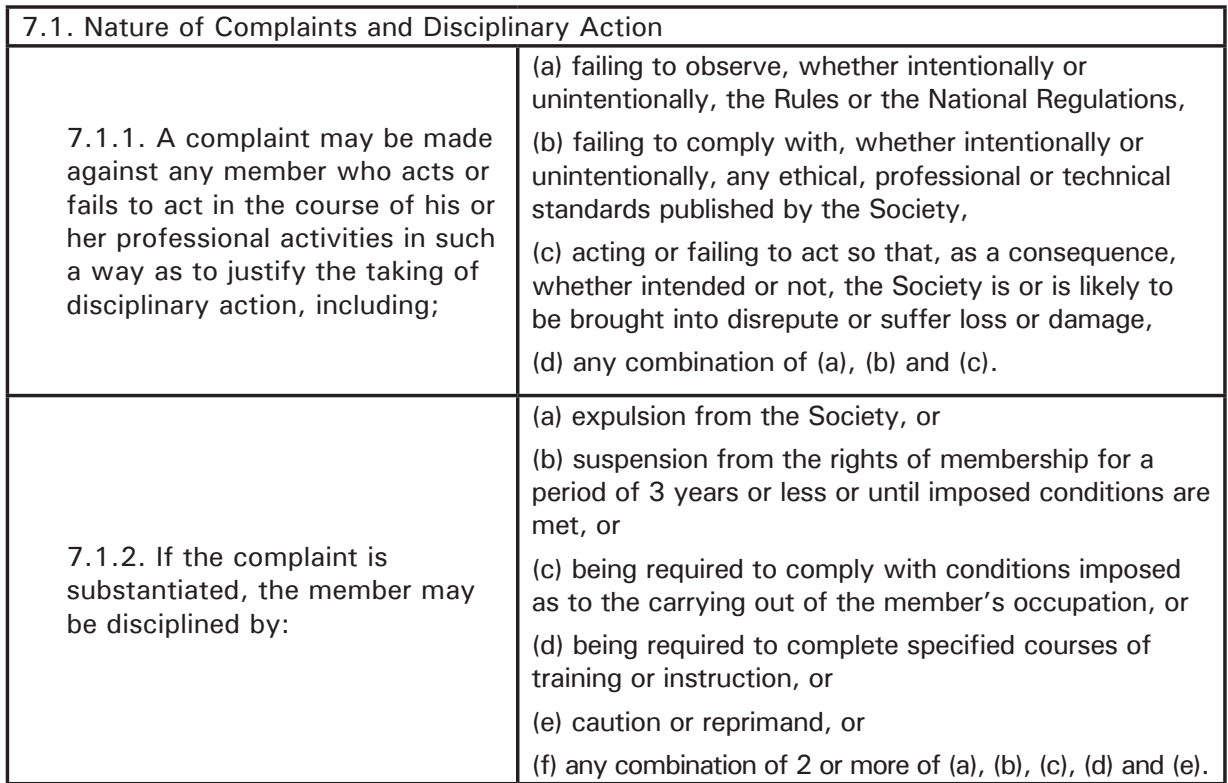

Source: ACS rules and regulations (ACS, nd)

The ACS encourages its members, and their employers, to view ethical behaviour as a risk-management strategy. Philip Argy, while president of the ACS, wrote 'the standards set for ACS membership and the ethics of professionalism provide a guaranteed credential for employers and board directors wanting to minimise their risk', and 'membership of the ACS at the professional level immediately conveys to the world that you are committed to the highest standards and maintain a level of knowledge, expertise and mental acuity that ensures you are more able to deliver requirements on time, on budget, and with less risk' (2006).

This notion of ethical behaviour as a risk management strategy is formalised such that an ICT practitioner, to graduate from the ACS's initial professional development program, must demonstrate capabilities listed in Table 2 (above). Additionally, the practitioner must demonstrate that he or she;

Carries out risk assessment within a defined functional or technical area of business. Uses consistent processes for identifying potential risk events, quantifying and documenting the probability of occurrence and the impact on the business. Refers to domain experts for guidance on specialised areas of risk, such as architecture and environment. Coordinates the development of countermeasures and contingency plans.

This second skills definition is taken from SFIA, specifically the business riskmanagement skill at the SFIA level 5 of responsibility titled 'Ensure, advise' (SFIA Foundation, 2008c). 


\section{How does the ACS achieve its learning objectives in teaching ethics?}

The ACS delivers initial and continuing professional development programs using its in-house educational group called ACSEducation. The initial professional development programs are all delivered online, while the majority of continuing professional development programs are delivered on-ground.

ACSEducation has three full-time staff, none of whom are routinely involved in active teaching. The teaching staff of ACSEducation are engaged on a sessional or voluntary basis and all are senior professional members of the ACS. Typically they have no formal training as educators and most work outside of ACSEducation as ICT practitioners. ACSEducation is supported by an advisory panel comprising senior ICT professionals from Australian public- and privatesector IT organisations and, from 2010, it has been governed by an independent academic board comprising senior university academics.

The ACSEducation Learning Management (LM) system is an open-source product that its developers, Moodle Pty Ltd (2008), claim to have designed on sound pedagogical principles. The product is used by many organisations, such as The Open University, United Kingdom (2005), both for managed learning and collaboration.

Professionalism and ethics are addressed in three ACS programs; at the postgraduate level through the ACS Professional Year (PYear) and CPe programs; and at the undergraduate and vocational levels through the ACS Diploma of Information Technology. In the diploma, professionalism and ethics topics are only assessed, with teaching provided through colleges independent of the ACS.

\section{Professional ethics at the postgraduate level}

Similar processes and practices are used for teaching professional ethics in the PYear and CPe Programs.

The PYear is a 12-month, job-readiness program comprising three formal subjects and a 12-week internship with a host company. Participants, typically, are recent graduates of university courses accredited by the ACS and most are international students seeking permanent residence in Australia. The PYear participants are student members of the ACS and thus bound by the ACS rules, especially as pertaining to the ACS code of ethics.

The CPe program comprises four subjects that are completed on a part-time basis, plus a period of mentoring where a participant works one-to-one with a senior member of the ACS. Participants in the CPe program, normally, are graduates of an ACS-accredited university degree with at least 18-months experience who are 
employed in an ICT-related role. Most are professional grade members of the ACS who, like their PYear colleagues, are bound by the ACS rules pertaining to ethics and professional conduct. Participants in the CPe program, typically, will start with the professional ethics subject titled Business, Legal and Ethical Issues.

Like their colleagues in the PYear, participants studying professional ethics in the CPe program use the ACSEducation LM system to access learning materials, submit assessment items, and contribute to weekly discussion forums. The following discussion provides a general overview of the ACS postgraduate professional ethics subject.

Students in the first week of the professional ethics subject are presented with the following statement:

In preparing this subject it has been assumed that you and your fellow students are over-achievers; self-motivated, disciplined, and determined to succeed. You have extensive prior knowledge and experience relevant to your study; you are open-minded about sharing your work and educational experiences; and you accept critical thinking as part of the learning process.

In this statement, the ACS is recognising that postgraduate study — specifically, postgraduate study in professional ethics — differentiates its participants from the majority of the population, including the majority of ICT practitioners. It implies that professional ethics is a specialised pursuit critical to the success of someone seeking to be, and to be recognised as being, an ICT professional.

All subjects in the CPe program require 8 to 10 hours of study per week for 13 weeks. The content of the professional ethics subject is structured as in Table 5 below.

Table 5: Content of Business Legal \& Ethical Issues subject

\begin{tabular}{|l|l|}
\hline \multirow{4}{*}{$\begin{array}{l}\text { Module } 1 \text { (weeks 1-3) The role } \\
\text { of IT Professionals in Business. }\end{array}$} & What is a professional? \\
\cline { 2 - 2 } & The client/professional relationship. \\
\cline { 2 - 2 } & $\begin{array}{l}\text { Corporate culture and personal values. } \\
\text { wrameworks to resolve ethical issues in the } \\
\text { workplace. }\end{array}$ \\
\hline Module 2 (weeks 4-6) Risk & Risk management principles and concepts: \\
\cline { 2 - 2 } Management Frameworks. & IT Risk Management. \\
\hline Module 3 (weeks 7-9) IT & IT Governance Regulatory Frameworks. \\
\cline { 2 - 2 } $\begin{array}{l}\text { Governance. } \\
\text { Module } 4 \text { (weeks 10-13) }\end{array}$ & $\begin{array}{l}\text { IT Governance's role in ISO/IEC38500:2006 IT } \\
\text { GOVERNANCE standard. }\end{array}$ \\
\hline Managing Risk in the Business. & $\begin{array}{l}\text { Risk management issues, challenges and } \\
\text { compliance with respect to social, business and } \\
\text { ecological environments. }\end{array}$ \\
\hline
\end{tabular}

Source: ACSEducation 
The ACS takes a more practical than normative approach to teaching professional ethics. Nowhere in the required readings, for example, is there mention of deontology or utilitarianism, though participants may encounter such concepts in their ancillary readings. Most effort is given to examining practical situations of ethical significance and discussing with colleagues the applicability to those situations of the ACS code of ethics, different risk-management frameworks, and standards of IT governance.

A teaching week in the ACS professional ethics subject has two sessions; Sunday to Wednesday and Thursday to Saturday. In the first session, participants work individually, reading and, based on their personal and professional experiences, answering tutor-supplied questions. In the second session they work collaboratively in cohorts of up to 20 discussing and debating the questions previously answered individually.

The role of the tutor in the professional ethics subject is to set questions and monitor discussions. Tutors must redirect dialogue that strays from the required theme, encourage less assertive participants to enter into an exchange of ideas, gently restrain dominating participants, and reprove participants who fail to contribute.

For their contribution to weekly discussions, participants are graded, as noted previously, with no differentiation between work at, and work above, an expected standard. It is assumed that work above an expected standard will necessitate a participant not fulfilling their responsibilities in another aspect of their life; maybe professional or family. In a similar vein, participants who contribute below an expected standard are not only awarded low marks, but they are told that their behaviour is unprofessional in that they are not assisting with the learning of their colleagues.

Assessment of discussion forums accounts for 20 per cent of the marks in the subject.

Weekly discussions rely on each participant sharing their knowledge, skills and experience with their colleagues with the aim to address, as expressed here by the International Federation of Accountants, the reality that;

In the case of complex ethical situations it is unlikely that there will be only one 'right' answer. While analysis may not give a single 'right' answer to a problem or dilemma, it may lead to one or more answers that are more consistent with the fundamental principles ... (2007)

The approach of using weekly discussions separates the CPe program from many others courses that teach professional ethics and, in the view of ACSEducation, this process increases its educational effectiveness. Participants are obliged to reflect upon professional ethics every day in their workplaces and debate points of view with colleagues whose workplaces may be different from their own. 
In Week 6 of their 13 weeks in the professional ethics subject, participants submit an assignment addressing ethical issues as described in three case studies. Again, quoting the International Federation of Accountants, the aim is;

By learning to analyze case studies and examples of ethical threats, individuals realize that problems and ethical dilemmas do have solutions. (2007)

For each case, the participants are expected to deliberate on the facts and provide an analysis of 750 to 1000 words. Most participants have difficulty in curtailing their responses to the word limit, and many complain that they need more space in which to express their arguments. A typical tutor's response to such complaints is something like: 'a professional must be able to express themselves clearly and succinctly so that their opinions and actions can be understood by those outside their profession'.

In addressing the case studies, the participants are expected to use an ethical framework, examples of which are provided in their readings, to guide them through the deliberation process. They must also compile a personal ethics matrix detailing the values they hold highly in the professional setting. For example;

Honesty, that quality of being honest in dealings with clients, colleagues and myself. Clauses might include a direct inclusion from the ACS Code of Ethics eg.

4.7.1 I must not knowingly mislead a client or potential client as to the suitability of a product or service.

4.7.2 I must not misrepresent my skills or knowledge.

4.7.3 I must give opinions which are as far as possible unbiased and objective.

4.7.4 I must give realistic estimates for projects under my control.

4.7.5 I must qualify professional opinions which I know are based on limited knowledge or experience.

4.7.6 I must give credit for work done by others where credit is due.

In dealing with this part of the assignment, participants are also asked to disclose their sources of inspiration which, by way of example, might be as diverse as the Bible, parents, partners and grandparents and even a popular television program. All such sources are acceptable, so long as the reason for their inclusion is argued satisfactorily. 
The first assessment accounts for 30 per cent of the marks in the subject.

At Week 13, students must submit a second assignment. This 1500-word paper reviews the values of either the organisation for whom the participant works, or another with which they are familiar. The participants must consider the relationship between values and ethics in the workplace and propose a plan to develop a new code of ethics for the organisation. They are not required to write an actual code, only to justify its need and prepare a plan for its implementation.

The second assignment accounts for 50 per cent of the marks in the subject.

The marking guide for the first assignment, which is provided to both tutors and participants, explains that marks are awarded according to criteria, such as:

- How extensive were your efforts to link the relevant theory, its challenges and the issues to the practical business situation?

And, for the second assignment:

- How comprehensive was the stakeholder perspective you developed?

- How relevant and workable are your recommendations?

- How well did you analyse the link between values and ethics?

\section{Professional ethics at the undergraduate level}

At the undergraduate level, in the ACS Diploma of Information Technology, ACSEducation offers a subject called Professional Practice. The undergraduate subject is not a cutdown version of the postgraduate subjects, but, rather, a unit of professional development refined over many years for technician-level membership of the ACS. Learning outcomes of the Professional Practice subject include:

- Understanding of the role of professional societies and the implications for professionals of their codes of ethics and practice, in particular the ACS code of ethics and code of professional conduct and professional practice.

- Understanding of the ethics and social responsibilities associated with being an information technology professional.

- Investigation of current issues associated with the use and abuse of information technology.

- Development of skills in analysing the social and ethical impact of information technologies.

In addition, the Professional Practice subject includes a unit of competency from the Australian Quality Training Framework (AQTF) (ACS, 2005). Called 'Ensuring privacy of users', the unit requires that students are able to: 
1. Review privacy policy in relation to legislation.

2. Determine policy shortfalls.

3. Update and review policies.

Assessing a unit of competency involves observing the demonstration of a skill; in this case, reviewing a privacy policy, determining its shortfalls against relevant legislation, and making updates.

To assess against both the learning outcomes and the unit of competency, ACSEducation provides candidates with workplace scenarios such as, that of a company that manufactures office furniture, a company that sells insurance, and an employment agency. In a three-hour exam, students are asked to answer questions such as those in Table 6 below.

\section{Table 6: Typical questions in an ACS Professional Practice examination}

\begin{tabular}{|c|c|}
\hline \multirow{4}{*}{$\begin{array}{l}\text { Question: Your project manager has } \\
\text { asked you to organise a meeting } \\
\text { to investigate the impact of the } \\
\text { proposed upgrade of the company's } \\
\text { Customer Interaction software. }\end{array}$} & who should attend the meeting; \\
\hline & $\begin{array}{l}\text { how the meeting should be held, bearing in } \\
\text { mind that attendees may be based at any of the } \\
\text { organisation's offices; and }\end{array}$ \\
\hline & $\begin{array}{l}\text { what documents should be circulated to attendees } \\
\text { prior to the meeting. }\end{array}$ \\
\hline & $\begin{array}{l}\text { Prepare a draft agenda for the meeting using an } \\
\text { agenda template you are familiar with. The agenda } \\
\text { should include proposed location(s) for the meeting, } \\
\text { and a list of agenda items that may address the } \\
\text { project manager's brief. }\end{array}$ \\
\hline \multirow{7}{*}{$\begin{array}{l}\text { Question: Prior to attending the } \\
\text { meeting your project manager has } \\
\text { asked you to undertake an ethical } \\
\text { analysis of the Interactions as } \\
\text { described in the question above, to } \\
\text { identify any issues or concerns that } \\
\text { should be addressed as part of the } \\
\text { new development process. To assist } \\
\text { you she has provided the following } \\
\text { list of questions for you to respond } \\
\text { to: }\end{array}$} & Who are the stakeholders \\
\hline & Which facts raise $\epsilon$ \\
\hline & $\begin{array}{l}\text { Identify a major ethical dilemma which must be } \\
\text { resolved. }\end{array}$ \\
\hline & $\begin{array}{l}\text { What are the rights and duties of each of the } \\
\text { stakeholders? }\end{array}$ \\
\hline & $\begin{array}{l}\text { What guidance does the Australian Computer } \\
\text { Society's Codes of Ethics provide in this situation? }\end{array}$ \\
\hline & $\begin{array}{l}\text { How would you resolve the dilemma identified in } \\
\text { point (c) above? Justify your decision. }\end{array}$ \\
\hline & How are the stakeholders affected by your decision? \\
\hline \multirow{3}{*}{$\begin{array}{l}\text { Question: You decide to investigate } \\
\text { existing privacy legislation to prepare } \\
\text { for the meeting. You also investigate } \\
\text { existing policies and procedures that } \\
\text { may relate to the legislation but find } \\
\text { none that are relevant. }\end{array}$} & $\begin{array}{l}\text { What type of legislation would you expect to find in } \\
\text { your search? }\end{array}$ \\
\hline & $\begin{array}{l}\text { What type of policies and procedures would you } \\
\text { recommend to be implemented? }\end{array}$ \\
\hline & $\begin{array}{l}\text { What actions would need to be taken to implement } \\
\text { the proposed policies successfully? }\end{array}$ \\
\hline
\end{tabular}

Source: Extracted from SFIA, 2008c 


\section{Techniques the ACS uses, are they good enough?}

The selection of ACSEducation teaching and assessment strategies, including those for teaching professional ethics, is influenced by the characteristics of its students, ACS certification requirements, and external accreditation frameworks.

\section{Student characteristics}

Gilly Salmon (2004), in her 'Model of online learning', provides the basic elements of the ACSEducation teaching strategy. An explanation of this model, and its associated principles, is provided in Lindley (2007).

While the appropriateness of the Salmon model for ACSEducation students - that is, adult learners who, typically, are highly motivated, IT literate and geographically dispersed — might seem self-evident; no thorough evaluation of its effectiveness has been undertaken. To overcome this deficiency, Lindley (2008) proposes a research methodology to answer the questions:

- Is the ACS CPe program effective and efficient?

- How can the ACS CPe program be improved to achieve its objectives better?

In essence, the methodology involves working with university researchers to compare ACSEducation techniques with those employed by organisations such as:

- Overseas ICT professional associations, for instance, the British Computer Society.

- Specialised ICT associations, for instance, the Information Systems Audit and Control Association (ISACA).

- Professional associations in disciplines other than ICT, such as the Institute of Chartered Accountants and Engineers Australia.

Focusing more broadly than solely on education in professional ethics, the aim is to investigate the areas listed in Table 7 below. 
Professionalism in the Information and Communication Technology Industry

Table 7: Points of comparison with other professional associations proposed for investigation by Lindley (2008)

\begin{tabular}{|c|c|}
\hline \multirow{4}{*}{ Association } & History and purpose. \\
\hline & Membership categories and entry requirements. \\
\hline & Number of members and recent membership trends. \\
\hline & Policies concerning professional development \\
\hline \multirow{8}{*}{$\begin{array}{l}\text { Professional } \\
\text { Development } \\
\text { Activities }\end{array}$} & Objectives for professional development. \\
\hline & Experience and history. \\
\hline & $\begin{array}{l}\text { Processes for recognition of prior learning, content } \\
\text { development, course delivery, assessment and quality } \\
\text { assurance. }\end{array}$ \\
\hline & Staff and resources. \\
\hline & Costs to students, subsidies, and scholarships. \\
\hline & Articulation arrangements for further education. \\
\hline & Marketing and promotion procedures. \\
\hline & Development plans. \\
\hline \multirow{6}{*}{$\begin{array}{l}\text { Specific Professional } \\
\text { Development } \\
\text { Program }\end{array}$} & Rationale and desired outcomes. \\
\hline & Initial or continuing professional development. \\
\hline & $\begin{array}{l}\text { Recognition under the Australian Qualifications Framework } \\
\text { (or equivalent). }\end{array}$ \\
\hline & Expected student commitment. \\
\hline & Student numbers and number of offerings. \\
\hline & Formal methods and models employed. \\
\hline
\end{tabular}

Source: Lindley 2008

\section{ACS certification requirements}

Successful completion of the ACS CPe and diploma programs can be used as evidence in support of an application for ACS membership. The learning outcomes of the postgraduate Business Legal \& Ethical Issues subject, for instance, are designed to be consistent with the professional ethics requirement for ACS professional level membership, and successful completion of the subject certifies that an applicant possesses the required ethics knowledge and skills.

A potential difficulty lies in assessment against desired learning outcomes. As noted previously, most teaching staff are not trained educators and the challenge is to ensure assessment accuracy and consistency. An obvious formative technique is for the small number of teaching staff who are professional educators to mentor their colleagues, but such activities cannot by themselves guarantee assessment accuracy. In the assessment-only undergraduate subject, Professional Practice, a simple comparison of pass rates with other subjects and other sessions provides a reasonable measure of consistency. In the postgraduate 
subject, however, because pass rates are consistently high, a more sophisticated approach is required. A useful measure, considered in combination with others, might be comparative 'did not complete' and 'deferred' rates across offerings.

\section{External accreditation requirements}

External education frameworks used by ACSEducation include the SFIA and the AQTF, defined by training.com.au as a 'set of standards which assures nationally consistent, high-quality training and assessment services' (2007).

External education frameworks offer two major advantages for ACSEducation programs. First, they impose discipline on course design. For example, the AQTF requires that a diploma-level course incorporate a minimum number of units of competency, each of which adheres to a prescribed level of difficulty. The second advantage is that they enable the community at large, beyond the ACS, to locate ACSEducation programs in the context of national and international systems of education.

The price, however, is that external frameworks change over time, and not always in a timely manner that is consistent with changes desired by ACSEducation programs. A recent change in the SFIA framework, for instance, from version 3 to version 4, has left some ACSEducation postgraduate subjects requiring changes to their learning outcomes, and perhaps also their content.

\section{References}

Argy, P, 2006, 'Professionalism is the best form of risk management', viewed 30 December 2008, <http://web.archive.org/web/20060919023218/http:// www.acs.org.au/news/oz010106.htm>

Australian Computer Society (ACS), nd, Rules \& Regulations, <http://acs.org. $\mathrm{au} /$ about-the-acs/governance/rules-and-regulations $>$

, 2005, 'Professional practice syllabus', as at 1 July 2005, viewed 29 September 2009, <http://www.acs.org.au/dit/index.cfm?action=show \&conID=ditprofessionalp $>\quad<$ http://www.acs.org.au/_data/assets/pdf_ file/0017/10178/Diploma-of-IT-ICA50105-Subjects-Syllabuses.pdf $>$

Australian Computer Society Professional Standards Board, 2007, 'Redefining and building the ICT profession: core body of knowledge review discussion paper', viewed 25 September 2009, <http://www.acs.org.au/_data/assets/ pdf_file/0007/7792/The-ICT-Profession-Body-of-Knowledge.pdf $>$ 
Australian Research Council, Linkage Projects, nd, viewed 1 July 2008, < http:// www.arc.gov.au/ncgp/lp/lp_default.htm>

Engineers Australia, 2009, viewed 25 September 2009, <http://www. engineersaustralia.org.au/education/continuing-professional-development/ continuing-professional-development.cfm $>\quad<\mathrm{http}$ ://www.engineersaustralia. org.au/professional-development/continuing-professional-development>

International Federation of Accountants, 2007, 'IEPS 1 - approaches to developing and maintaining professional values, ethics, and attitudes', viewed 30 September 2009, <http://www.ifac.org/Members/Pubs-Details. tmpl?PubID=119151330213823\&Category=Education $>\quad<$ http://www.ifac. org/sites/default/files/publications/files/ieps-1-approaches-to-deve.pdf>

Lindley D, 2007, 'Computer professional education using mentored and collaborative online learning', SEARCC 2007, Proceedings of the South East Asia Regional Computer Conference, 18-19 November, Bangkok, Thailand, viewed 30 December 2008 <http://www.ijcim.th.org/v15nSP4/ P09SEARCC_ComputerProfessionalEducation.pdf > <http://www.ijcim.th.org/ SpecialEditions/v15nSP4/P09SEARCC_ComputerProfessionalEducation.pdf $>$

, 2008, 'A research proposal to assess the efficacy of initial professional development offered by professional associations, in particular, the Computer Professional Education Program offered by the Australian Computer Society, SOCIAL INCLUSION - engaging the disengaged in life wide learning', Proceedings of the Adult Learning Australia 48th Annual National Conference, November, Fremantle Western Australia.

Moodle Pty Ltd., 2008, 'Philosophy', viewed 30 December 2008, <http://docs. moodle.org/en/Philosophy>

The Open University, 2005, 'The Open University builds student online environment with Moodle and more', viewed 30 September 2009, <http:// www3.open.ac.uk/media/fullstory.aspx?id=7354>

Professions Australia, 1997, 'Definition of a profession, viewed 30 December 2008, <http://www.professions.com.au/defineprofession.html>

Salmon, G., 2004, E-moderating: The key to teaching and learning online, 2nd edn, Taylor \& Francis, London.

SFIA Foundation (2008a), Getting it right with SFIA, viewed 25 September 2009, <http://www.sfia.org.uk/cgi-bin/docs.pl/IntroLeafletSFIAv4.pdf>

— 2008b, Skills framework for the information age, viewed 25 September 2009, $<$ http://www.sfia.org.uk/cgi-bin/docs.pl/ChartFramework_SFIAv4.pdf> 
- 2008c, Framework reference SFIA version 4: Skill definitions in categories, subcategories and skills, viewed 25 September 2009, <http://www.sfia.org. uk/cgi-bin/docs.pl/ReferenceGuideSFIAv4.pdf>

training.com.au, 2007, AQTF 2007 - A better system for everyone, viewed 30 December 2008, <http://www.nssc.natese.gov.au/nqc_archive/aqtf>

UK Initial Professional Development Forum, undated, viewed May 2008, $<$ http://www.ukipdforum.co.uk> 